\title{
Current Conditions and Problems of Conservation and Inheritance of Identity Among Thai-Sikhs
}

\author{
Nakrob Narksuwan ${ }^{1}$, Wisanee Siltragool ${ }^{1} \&$ Anchalee Jantapo $^{1}$ \\ ${ }^{1}$ The Faculty of Cultural Science, Mahasarakham University, Khamriang Sub-District, Kantarawichai District, \\ MahaSarakham, Thailand \\ Correspondence: Nakrob Narksuwan, Mahasarakham University, Khamriang Sub-District, Kantarawichai \\ District, Maha Sarakham 44150, Thailand. E-mail:nnarksuwan118@hotmail.com
}

Received: June 30, 2014 Accepted: July 4, 2014 Online Published: September 22, 2014

doi:10.5539/ach.v7n1p1 URL: http://dx.doi.org/10.5539/ach.v7n1p1

\begin{abstract}
This research is aimed at investigating the current conditions and problems of conservation and inheritance among Thai Sikhs in metropolitan Bangkok. Data was gathered by means of interview, observation, group discussion, and workshop. The study area was comprised of Pahurat, PraNakorn District, Gurdwara Sri Guru Singh Sabha, PraNakorn District, and Im-Amporn Village, Bangkok Yai District. The results show that the most important aspects of Thai-Sikh identity that must be conserved are the 5 sacred symbols, fundamental teachings, religious ceremonies, the Gurdwara Sri Guru Singh Sabha religious building, the Sri Guru Singh Sabha Association and the Punjabi language. Currently, Thai-Sikh identity is clear and well-maintainedin Bangkok society. However, problemsare caused by westernization and adoption of modern cultural practices from other societies. This leads to the neglect of traditional Thai Sikh lifestyle. The suggested solutions include raising awareness of identity conservation among Thai Sikhs, which requires the cooperation of the government and private sectors. Training and activities must also be arranged, which new Thai-Sikh generations can learn from and participate in.
\end{abstract}

Keywords: Thai-Sikh, identity, conservation, inheritance, Bangkok

\section{Introduction}

The word identity refers to the specific characteristics of an individual, object, concept, group or entity. It is the things for which people and groups are known, their defining traits. Each society has its own identity. Westernization and adoption of modern cultural practices from other societies have cause traditional Thai society to change, especially in human behavior and everyday activities. These include food, dress, occupations and entertainment. Identities are often molded to fit natural and constructed surroundings, which is how Thai-Sikhs migrating from India have conducted business, settled and adapted to life in predominantly Buddhist Bangkok society. This has been achieved with simultaneous maintenance of the important aspects of Sikh culture.

Sikhs come from Punjab, which is a region in Northern India. Sikh people first came to Thailand during the reign of King Rama IV. In the reign of King Rama V, they settled at Baan Mor, Pahurat, PraNakorn District, Bangkok. After acclimatizing, they began selling textiles to generate income. The Gurdwara was constructed as the main Sikh holy building in 1912. This was the case until the local Sikh community outgrew the existing Gurdwara and required an expanded religious facility, which was provided between Pahurat and Chakpetch Roads. Upon completion of the new Gurdwara, Sikh religious rites were relocated, where they have remained until the present day. Most Thai Sikhs live in the Bangkok area, since Bangkok is the center of politics, economy, society and culture. Nowadays there are over 70,000 Sikhs in Thailand and 18 officially recognized Sikh holy buildings (Siri Guru Singh Sabha Association, 2013).

Aside from the differences between Thai and Sikh cultures encountered by Thai-Sikhs living in Bangkok, there are also influences of modern global culture that threaten the traditional identity of Sikh people. The danger is that the modern culture being absorbed by young Thai-Sikhs will supersede their traditional heritage. In light of this, the researchers wanted to study ways of conservation and succession of Sikh identity to find an appropriate model of conservation and succession of the identities of other ethnic groups and communities.

\section{Research Methodology}

This investigation aims to study the history and identity the Thai Sikhs in Metropolitan Bangkok. The goal of the research is to analyze the current situations and problems of Thai Sikh identity conservation and to study the 
model for its succession to ensure peaceful assimilation and harmony of Sikhs in Thai society. A qualitative research technique was applied to this study. The study area was comprised of Pahurat, PraNakorn District, Gurdwara Sri Guru Singh Sabha, PraNakorn District, and Im-Amporn Village, Bangkok Yai District. The population of the investigation was comprised of people living and working in and around the study areas. The research sample was selected using a purposive sampling technique and was divided into three groups: key informants, casual informants and general informants. Data was gathered by means of interview, observation, group discussion, and workshop. All collected field data was validated using a triangulation technique according to time, place, method of collection and researcher. The data was organized according to the aims of the research and divided into sets or typologies to facilitate a typological analysis. Analytical induction was employed as a secondary analysis method. The research results are here presented using analytical description according to the obtained data.

\section{Results}

The results show that Thai resources draw immigrants to the country for the purpose of trade or settlement. Another factor is religious freedom. Most importantly, the Thai King is kind to refugees. Many ethnic groups have flown into Thailand, especially Indians. Apart from settling down in Thailand, Indians are also well-known for their trading activities and their strong sense of identity. According to a letter from Prince Nares Worarit to the King, Sikh people first came to Thailand during the reign of King Rama IV. However, interview results concluded the general acceptance that most Sikhs followed when King Rama V was on the throne. In the reign of King Rama V, they settled at Baan Mor, Pahurat, PraNakorn District, Bangkok. After acclimatizing, they began selling textiles to generate income. Indeed, they came to Thailand primarily from Punjab for the purpose of trade. The main trading center was around Pahurat Road. Some of the Sikhs were peddlers, travelling around to sell fabric. When the Sikh population had increased, the Gurdwara was established as the main Sikh holy building at a rented house on Pahurat Road in 1912. This was the case until the local Sikh community outgrew the existing Gurdwara and required an expanded religious facility, which was provided between Pahurat and Chakpetch Roads in 1932. Upon completion of the new Gurdwara, Sikh religious rites were relocated, where they have remained until the present day. Now, they earn their livings from all fields. Even though some Sikhs moved from Pahurat, they still return, for it is the center of their religious ceremonies and trading.

The most important aspects of Thai-Sikh identity that must be conserved are the 5 sacred symbols, fundamental teachings, religious ceremonies, the Gurdwara Sri Guru Singh Sabha religious building, the Sri Guru Singh Sabha Association and the Punjabi language. The five sacred symbols of Thai Sikhs are the five things that they must carry or observe from the time of their entry into the Sikh faith as a child. These are: 1) keeping their hair long under a turban; 2) a small-sized comb for maintaining their hair condition; 3) a metal bracelet for their wrist; 4) a miniature knife pendant hung onto a necklace; 5) a pair of shorts. Females must observe the same symbols, with the exception of the first. In its place, they must keep their hair neatly under a cloth scarf. Thai Sikh ceremonies are derived from the Guru Granth Sahib Holy Scripture. These are primarily based on self-control and personal conduct in society. The secondary and tertiary principles are leading a philosophical daily life and providing assistance to society. The ceremonies observed in the everyday life of a Thai Sikh are aimed at maintaining Sikh traditions and include both organized religious and secular events. All Sikh people come from far and wide to perform their acts of worship at the most sacred holy place for their faith in Thailand, the Gurdwara Sri Guru Singh Sabha religious building. The Siri Guru Singh Sabha Association was registered with the National Council of Cultural Affairs in 1963. The Thai government declared that holy establishments must be affiliated to the Department of Religious Affairs. The Association was accordingly signed up and Sikhism was thus considered a legitimate religion in Thailand. The headquarters of the Siri Guru Singh Sabha Association is situated onPahurat Road, Bangkok. Their function is to preserve traditional Sikh customs, preach Sikh scripture and instruct young Thai Sikhs. Additionally, The Association helps organize the activities in the Gurdwara. The basic language of Sikh scripture is Punjabi, which is used for all written teachings and communication between Thai-Sikhs. For this reason, all Thai-Sikhs must learn the language in its written and spoken forms in order to be able to successfully worship and understand Sikhism. Moreover, the ability to understand Punjabi facilitates communication in the wider Sikh world.

Problems are caused by westernization and adoption of modern cultural practices from other societies. This leads to the neglect of traditional Thai Sikh lifestyle. Results show that the five Sikh symbols are: 1) keeping their hair long under a turban; 2) a small-sized comb for maintaining their hair condition; 3) a metal bracelet for their wrist; 4) a miniature knife pendant hung onto a necklace; 5) a pair of shorts. Interviews with key informants show that the biggest problems revolve around the first symbol. Many Sikh men are required by their employers to cut their hair short and shave facial hair, which causes conflict with the traditional Sikh practices. Further problems 
are caused by the influence of Western fashion styles, notably haircuts and hair dyes. Modern culture also causes young Sikhs to neglect their religious instruction by smoking, drinking alcohol and not worshipping as often as they should. Organization and attendance of religious ceremonies are also not disciplined. Maintenance of the holy buildings is affected by a lack of public participation and insufficient budget, which is partially due to the insignificance of Sikhism for the non-Sikh Thai population. Given the small numbers of Thai-Sikh people in the country, there is a small field of resources to draw from to comprise the Siri Guru Singh Sabha Association, which means that council members are occasionally unqualified or unsuited for the roles they are chosen to fill. The preservation of Punjabi is also a very problematic undertaking given its minimal value in everyday Thai society, lack of basic understanding among Thai-Sikh youth and a declining population of qualified teachers.

\section{Discussion}

Thai resources draw immigrants to the country for the purpose of trade or settlement. Another factor is religious freedom. Most importantly, the Thai King is kind to refugees. Many ethnic groups have flown into Thailand, especially Indians. Apart from settling down in Thailand, Indians are also well-known for their trading activities and their strong sense of identity.These results correspond to the research of W.H. Mclead (2004) in his study of Sikhs and Sikhism. Indeed, all historical findings concluded by this investigation corroborate the background of Sikhs in Thailand provided by Sidhu Manjet (1993).

The five sacred symbols of Thai Sikhs are the five things that they must carry or observe from the time of their entry into the Sikh faith as a child. These are: 1) keeping their hair long under a turban; 2) a small-sized comb for maintaining their hair condition; 3) a metal bracelet for their wrist; 4) a miniature knife pendant hung onto a necklace; 5) a pair of shorts. These symbols are identical to the symbols identified by J.D. Cunningham (1853) in his History of the Sikhs. This shows that the principles of Sikh identity have remained largely constant since scholarly research on the religion began.

Problems with the maintenance of Sikh culture are caused by westernization and adoption of modern cultural practices from other societies. This has been well documented by the Siri Guru Singh Sabha Association (2003a; 2003b; 2007; 2008; 2013; n.d. a; n.d. b). Problems can be found in each of the major categories of Sikh identity: the 5 sacred symbols, fundamental teachings, religious ceremonies, the Gurdwara Sri Guru Singh Sabha religious building, the Sri Guru Singh Sabha Association and the Punjabi language. This leads to the neglect of traditional Thai Sikh lifestyle. The suggested solutions include raising awareness of identity conservation among Thai Sikhs, which requires the cooperation of the government and private sectors. Training and activities must also be arranged, which new Thai-Sikh generations can learn from and participate in.

\section{Conclusion}

The results show that the most important aspects of Thai-Sikh identity that must be conserved are the 5 sacred symbols, fundamental teachings, religious ceremonies, the Gurdwara Sri Guru Singh Sabha religious building, the Sri Guru Singh Sabha Association and the Punjabi language. Currently, Thai-Sikh identity is clear and well-maintainedin Bangkok society. However, problems are caused by westernization and adoption of modern cultural practices from other societies. This leads to the neglect of traditional Thai Sikh lifestyle. The suggested solutions include raising awareness of identity conservation among Thai Sikhs, which requires the cooperation of the government and private sectors. Sikh families should apply traditional Sikh practices to their lives and the upbringing of their children, since family is the first place where knowledge about Sikhism, including teachings, ceremonies, practices and Punjabi language are educated. Training and activities must also be arranged, which new Thai-Sikh generations can learn from and participate in.

\section{References}

Cunningham, J. D. (1853). History of the Sikhs. London: Oxford University Press.

Mclead, W. H. (2004). Sikhs and Sikhism. London: Oxford University Press.

Opindenrjit, K. T. (2005). Sikh Identity: An Exploration of Group Armonk Sikhs. London: Ash gate Publishing Ltd.

Public Policy Development Office. (2006). The indicator of Thai happiness. Bangkok: Public Policy Development Office.

Sidhu Manjet, S. (1993). Sikhs in Thailand. Bangkok: Institute of Asian Studies, Chulalongkorn University press.

Singh, K. (1966). A History of the Sikh: 1839 - 1964(Vol. 2). Princeton: Princeton University Press.

Singh, S. (2000).The Guru's word illustrated Sikh History. Princeton: Princeton University Press. 
Siri Guru Singh Sabha Association. (2003A).Guru Gobind Singh.Bangkok: Siri Guru Singh Sabha Association.

Siri Guru Singh Sabha Association. (2003B). Guru Nanak, the founder of the Sikhism. Bangkok: Siri Guru Singh Sabha Association.

Siri Guru Singh Sabha Association. (2007). Religious discipline of Sikhism. Bangkok: Siri Guru Singh Sabha Association.

Siri Guru Singh Sabha Association. (2008). The gateway to Thai Sikhism:ChaloemPhraKiat. Bangkok: Siri Guru Singh Sabha Association.

Siri Guru Singh Sabha Association. (2013). Japi Sahib. Bangkok: The Committee of Siri Guru Singh Sabha.

Siri Guru Singh Sabha Association. (n. d. a). Sikhism. Bangkok: Burapasin Publishers.

Siri Guru Singh Sabha Association. (n. d. b). What is Sikhism? Bangkok: Siri Guru Singh Sabha Association.

\section{Copyrights}

Copyright for this article is retained by the author(s), with first publication rights granted to the journal.

This is an open-access article distributed under the terms and conditions of the Creative Commons Attribution license (http://creativecommons.org/licenses/by/3.0/). 